\title{
Inheritance of resistance to oat crown rust in recombinant inbred lines
}

\author{
Felipe André Sganzerla Graichen ${ }^{1}$; José Antônio Martinelli2*; Luiz Carlos Federizzi³; \\ Marcelo Teixeira Pacheco ${ }^{3}$; Márcia Soares Chaves ${ }^{4}$; Caroline de Lima Wesp ${ }^{1}$ \\ ${ }^{1}$ UFR GS - Programa de Pós-Graduação em Fitotecnia. \\ ${ }^{2}$ UFRGS - Depto. de Fitossanidade, Av. Bento Gonçalves 7712 - 91540-000 - Porto Alegre, RS - Brasil. \\ ${ }^{3}$ UFRGS - Depto. Plantas de Lavoura. \\ ${ }^{4}$ Embrapa Trigo, Rod. BR 285, km 294 - 99001-970 - Passo Fundo, RS - Brasil. \\ *Corresponding author <jamfito@ufrgs.br>
}

\begin{abstract}
Crown rust is the main disease affecting oats (Avena sativa L.), and genetic resistance has been the chief method utilized to control this disease. A population composed of 135 recombinant inbred lines, $\mathrm{F}_{5: 6}$, generated by crossing the oat cultivar UFRGS 8 with the genotype Pc68/5*Starter, was assessed on the inheritance of resistance to crown rust (Puccinia coronata f. sp. avenae P. Syd. \& Syd.). The evaluation of resistance in $\mathrm{F}_{5: 6}$ seedlings was based on the type of infection resulting from inoculation with the race SQPT of $P$. coronata f. sp. avenae. The proportion of Resistant: Susceptible seedlings (R:S) was 62:64, which indicates that inheritance was governed by a single gene. The assessment of resistance inheritance in adult plants was performed in the field during the years 2004 and 2005. The distinction between resistant and susceptible classes was based on the final severity (FS) as well as the area under the disease progress curve, which was normalized and corrected (AUDPC $* \mathrm{c}$ ). $\mathrm{F}_{5 \cdot 6}$ and $\mathrm{F}_{5 \cdot 7}$ were evaluated under field conditions in 2004 and 2005, demonstrating a ratio of approximately 1R:3S, which fits with a typical two genes inheritance model.

Key words: Avena sativa, Puccinia coronata f. sp. avenae, Pc68 gene, race-specific resistance
\end{abstract}

\section{Herança da resistência à ferrugem da folha da aveia em linhagens recombinantes}

\begin{abstract}
RESUMO: A ferrugem da folha é a principal doença que afeta a aveia (Avena sativa L.), e a resistência genética é o método mais usado para seu controle. Uma população composta por 135 linhagens recombinantes $\mathrm{F}_{5: 6}$, gerada do cruzamento entre a cultivar de aveia UFRGS 8 e o genótipo Pc68/5*Starter foi avaliada quanto à resistência à ferrugem da folha (Puccinia coronata f. sp. avenae P. Syd. \& Syd.). A avaliação em plântulas foi baseada no tipo de infecção produzido quando inoculadas com a raça SQPT do patógeno. A proporção entre plântulas resistentes e suscetíveis (R:S) foi de 62:64, o que indica uma herança governada por um único gene. A avaliação da herança da resistência em plantas adultas foi realizada em condições de campo nos anos 2004 e 2005. A distinção entre as classes resistentes e suscetíveis foi baseada na severidade final (SF) e na área sob a curva de progresso da doença normalizada e corrigida (ASCPD*c). As populações $\mathrm{F}_{5: 6}$ e $\mathrm{F}_{5: 7}$ foram avaliadas no campo nos anos de 2004 e 2005, demonstraram uma proporção de aproximadamente 1R:3S, o que se ajusta a um modelo de herança governado por dois genes.

Palavras-chave: Avena sativa, Puccinia coronata f. sp. avenae, gene Pc68, resistência específica à raça
\end{abstract}

\section{Introduction}

Crown rust is the main disease affecting oats (Avena sativa L.) in all regions of crop growth (Simons, 1985; Martinelli, 2000). The damage caused by crown rust is dependent upon the duration and intensity of the epidemic, among other factors. In Brazil, the genetic diversity and complexity of this rust is extremely high (Leonard and Martinelli, 2005), and reductions in grain yield may be greater than 50\% (Martinelli et al., 1994).

Genetic resistance has been the chief method utilized to control this disease. Thus, far more than a hundred genes have been identified that confer race-specific resistance in oats. Virulent races of $P$. coronata f. sp. avenae P. Syd. \& Syd. have been described exhibiting resistance to all of these genes, although the frequency of virulent races (or isolates) exhibiting resistance to some of these genes has remained low over the years. Leonard and Martinelli (2005) found only $2 \%$ of $P$. coronata f. sp. avenae races that were virulent to plants containing the Pc68 gene in southern Brazil. This led to the hypothesis that this may be the only gene that still has potential utilization for breeding programs in that environment. Similarly, in North America, the frequency of virulent isolates to plants containing the Pc68 gene ranged from $1 \%$ to $2 \%$ of the isolates during the 1990 s (Leonard, 2003). The low frequency of virulent races for the Pc68 gene has been observed in several locations around the world, such as Estonia (Sooväli and Koppel, 2003), South Africa (van Kiekerk et al., 2001) and Mexico (Leonard et al., 2005). Despite the known potential of this gene, there is no available Brazilian cultivar (or South American) that 
exhibits resistance conferred by this gene. In comparison, a few cultivars have been released in Canada that contain the gene Pc68 since the 1990s (McCallum et al., 2007). However, the presence of races virulent to the Pc68 gene was detected during 1996, and the frequency of these variants increased gradually over the next three years (Chong, 2000).

Considering the potential use of the Pc68 gene in the breeding programs of southern Brazil, this study aimed to determine the resistance inheritance conferred by this gene in oat recombinant inbred lines, and to investigate the efficacy of the Pc68 gene when exposed to a favorable environment for the development of the disease.

\section{Material and Methods}

Genetic material: For the analysis of segregation and the source of resistance, 135 recombinant lines of oats (A. sativa $\mathrm{L}$.) were used with the $\mathrm{F}_{5: 6}$ and $\mathrm{F}_{5: 7}$ generations originating from crossing the susceptible cultivar UFRGS 8 (OA $338 * \mathrm{X}$ 2682-1) with the resistant genotype Pc68 $/ 5 *$ Starter, which were advanced by SSD without selection from the $\mathrm{F}_{2}$ generation onwards. UFRGS 8 is a former Brazilian cultivar of oats with daylenght insensitivity, good grain yield and resistant to crown rust when it was released in 1985 and it is now susceptible to the prevalent races and, Pc68/5*Starter is a North American line possessing the resistant gene Pc68.

Test on seedlings: Seeds of line $F_{5: 6}$ were sown in plastic pots filled with $150 \mathrm{~mL}$ of substrate. In each pot, 10 seeds of each genotype were sown. Due to the poor germination of some genotypes, only 126 of the 135 lines were utilized for this test. The cultivar UFRGS 8 and genotype Pc68/5* Starter served as controls. On the same day, the set of genotypes that compose the differential collection were also sown to determine the races of $P$. coronata f. sp. avenae (Chong et al., 2000). Seedlings were incubated in growth chamber under controlled conditions, with a photoperiod adjusted for $16 \mathrm{~h}$ of light and $8 \mathrm{~h}$ of darkness at a temperature of $22 \pm 2^{\circ} \mathrm{C}$ until 18 days after sowing (DAS). Then, the seedlings were transferred to a greenhouse. Seedlings were inoculated at 12 DAS, at the appearance of the first fully expanded leaf. The inoculation was performed with the race SQPT of $P$. coronata $\mathrm{f}$. sp. avenae, which is avirulent to plants containing the Pc68 gene and to the cultivar UFRGS 8.

Inoculation was performed by shaking the leaves of cultivar UFRGS 8, where the inoculum was multiplied, over and between the healthy seedlings. The seedlings were then sprayed with an aqueous solution of $\mathrm{Tween}^{\circledR}$ 20 at the concentration of $1 \mathrm{~mL} \mathrm{~L}^{-1}$ and kept in the dark in a moist chamber for $20 \mathrm{~h}$ at a temperature of $22 \pm$ $2{ }^{\circ} \mathrm{C}$. Assessment of the disease was performed 15 days after inoculation and the infection type (IT) on seedling leaves was scored according to the method of Chong et al. (2000), using a scale from 0 to 4 , where $0=$ absent uredia or other macroscopic infection symptoms, $1=$ small uredia surrounded by chlorosis or necrosis, $2=$ small to medium size uredia surrounded by chlorosis, 3 $=$ medium size uredia in a chlorotic area, and $4=$ large uredia without chlorosis or necrosis. Responses 0,1 , and 2 were considered indicative of host resistance, whereas 3 and 4 were indicative of host susceptibility.

Test with adult plants under field conditions: These tests were conducted in Eldorado do Sul, state of Rio

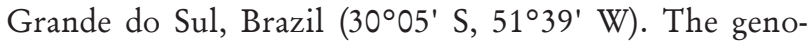
types were planted in plots composed of two lines, each one with $2 \mathrm{~m}$ length and $20 \mathrm{~cm}$ spaced apart. The distance between plots was $40 \mathrm{~cm}$. Approximately 100 seeds were sown in each plot. The first experiment commenced on June $18^{\text {th }}, 2004$ and consisted of 135 F5:6 oat lines sown in two replicates. The second experiment commenced on June $24^{\text {th }}, 2005$ and consisted of 134 lines $F_{5: 7}$ plus the parents, with four replicates. Plants were naturally inoculated with spores of $P$. coronata $\mathrm{f}$. sp. avenae. The intensity of crown rust was evaluated by scoring the severity of the disease, considering all leaves per plants and determining the average of readings per plot, based on Coob's modified diagrammatic scale ranging from 0 to $100 \%$ (Peterson et al., 1948). The last assessment of the disease severity was denoted as the final severity (FS).

Following evaluation of the disease throughout the disease cycle, the progress curve for each genotype was constructed and utilized to estimate the Area Under the Disease Progress Curve, which was normalized and corrected (AUDPC $*$ c) with the formula: ASCPD $* \mathrm{c}=\{\mathrm{S}$ $\left.\left\{\left[\left(\mathrm{y}_{\mathrm{i}}+\mathrm{y}_{\mathrm{i}+1}\right) / 2\right] *\left(\mathrm{t}_{\mathrm{i}+1}-\mathrm{t}_{\mathrm{i}}\right)\right\}\right\} / \mathrm{n} * \mathrm{c}$; where $\mathrm{yi}=\%$ of leaf area affected by the rust severity in the $i^{\text {th }}$ observation; ti = time in days after the beginning of the disease at the $i^{- \text {th }}$ observation; $\mathrm{n}=$ period of days between the beginning of the disease and latest disease assessment (adapted from Fry, 1978), and c = the longest cycle epidemic amongst the genotypes tested.

Data Analysis: A scale of 0 to 4 was used during this study, as previously described (Chong et al., 2000). The seedlings that received infection scores equal or smaller than 2 were considered resistant, and those with scores greater than 3 were considered susceptible. The data for FS and AUDPC*c were analyzed using descriptive statistics. The distribution of the frequency of these variables and the construction of histograms were performed using the program BioEstat (Ayres et al., 2003). The number of classes for frequency distribution was calculated by the empirical formula $\mathrm{C}=\sqrt{ } \mathrm{N}$, where $\mathrm{N}$ $=$ number of observations evaluated. Value zero was used for the variables FS and AUDPC*c for an individual class in 2004.

In 2004, the lines that did not exhibit disease throughout the entire season period, with AUDPC*c equal to zero, were considered resistant. The other lines were considered susceptible. However, the limits for the resistant lines were altered during the next year, when the environment was more favorable for the disease. Thus, the lines that had FS or AUDPC*c values lower than 
the average of the resistant parent (Pc68/5*Starter) were considered resistant in 2005 , with values corresponding to $3.92 \%$ for FS and 76.17 for AUDPC $*$ c, respectively. These resistance criteria were based on the fact that these levels of disease are low and do not reach the economic threshold. Pc68/5*Starter exhibited similar or lower levels of disease intensity in 2006, 2007, and 2008 (data not shown).

The ratio of resistant to susceptible lines (R:S) was subjected to the test of goodness of $\chi^{2}$ with Yates' Continuity Correction (Zar, 2009). The expected frequency of resistant to susceptible lines (R:S) was tested from 1:1, $3: 1$, and 1:3. Each of these situations could be achieved when: (i) there is only a single gene for resistance, and the proportion of R:S and the possible genotypes would be 1R (AA):1S (aa); (ii) there are two effective genes for resistance working independently, and the proportion of $R: S$ and the possible genotypes would be $3 R$ (AABB, $A A b b$ and $a a B B): 1 S$ (aabb); and (iii) there are two genes for resistance, which are only effective through epistasis, resulting in the proportion of $\mathrm{R}: \mathrm{S}$ and the possible genotypes $1 \mathrm{R}(\mathrm{AABB}): 3 \mathrm{~S}$ (AAbb, aaBB and aabb) or $1 \mathrm{R}$ (aabb):3S (AABB, AAbb and aaBB).

\section{Results}

The cultivar UFRGS 8 and the genotype Pc68/5* Starter were classified as susceptible (IT 3) and resistant (IT 0), respectively, to race SQPT of $P$. coronate $\mathrm{f}$. sp. avenae. Lines $F_{5: 6}$ showed infection types varying between (0) and (3). Of these, 62 lines were classified as resistant (IT 0 to 2), and 64 were classified as susceptible (IT 3). In 2004 the observation of the first pathogen pustules occurred on August 29, 72 DAS. After that
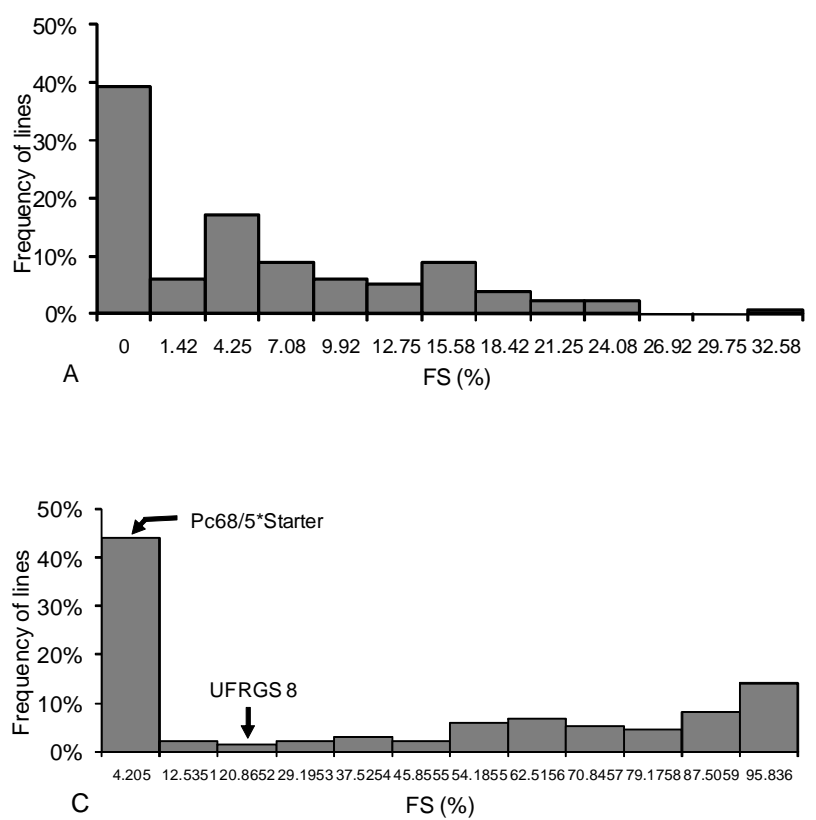

disease severity was evaluated on September 10, 15, 23, 29, October 4, and 15. Disease severity was monitored for 47 days. The final severity of crown rust ranged from $0 \%$ to $34 \%$. In the field, 64 lines (47\%) exhibited low FS, with values between zero and $2.83 \%$, and this class had the highest number of individuals (Figure 1A). Among this class, a final severity equal to zero was exhibited by 53 lines, which corresponded to $38 \%$ of the sample. Values of AUDPC*c equal to zero were obtained for 36 lines (26\%) (Figure 1B). Of these, 32 $(24 \%)$ had an infection type (0) in the seedling assessment, and the others had an infection type (3) or were not assessed.

In 2005 the environmental conditions were more favorable for the development of crown rust. Disease severity was evaluated 13 times, during 76 days, on the following dates: August 5 (42 DAS), 11, 19, 26, September 5, 16, 22, 26, 29, October 3, 6, 13, and 20. The resistant parent Pc68/5*Starter exhibited an average final severity of $3.92 \%$, while UFRGS 8 comprised only $16.67 \%$ (Figure 1C). Although the FS reached by the susceptible parent in 2005 was not very high, the pattern of the disease progress (Figure 2) indicates a clear difference in susceptibility of UFRGS 8 in relation to the resistant parent Pc68/5*Starter. Among the lines, the severity of the final reading ranged from $0.05 \%$, which means only traces of the disease, to $100 \%$. The AUDPC $* \mathrm{c}$ of crown rust for the lines ranged from 2.99 to 2099. The parental lines demonstrated AUDPCc* values of 78.28 and 459.97 for Pc68/5*Starter and UFRGS 8, respectively (Figure 1D).

The analysis of seedlings resistance to the pathogen demonstrated a monogenic inheritance, which is in agreement with the test of goodness of $\chi^{2}$ for the hypothesis
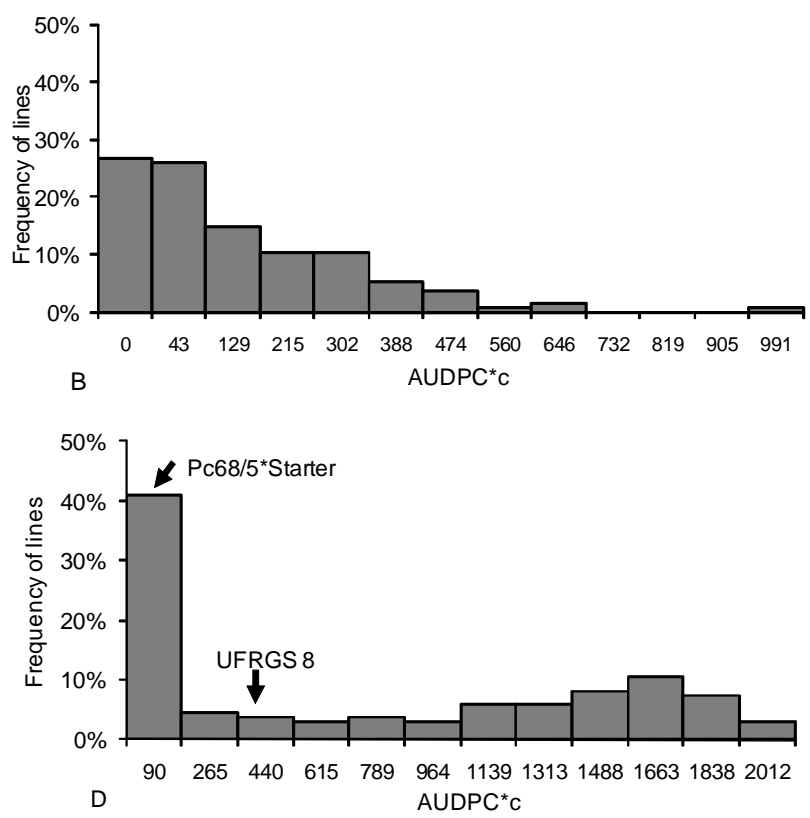

Figure 1 - Distribution of the frequency of the final severity and AUDPC*c of crown rust in oat recombinant lines from the crossing of UFRGS 8 and the genotype Pc68/5*Starter. A and B) evaluation of 135 lines in 2004. C and D) evaluation of 134 lines in 2005, indicating the class that involves the parents. Values in the axis of abscissa indicate the center of class. 
of segregation 1R:1S $(p=0.93)$ (Table 1). In contrast, in the field assessment in 2004, only 32 lines (25\%) were immune to the pathogen. The proportion of R:S adjusts to the model of inheritance governed by two genes, where the expected ratio is $1 \mathrm{R}: 3 \mathrm{~S}$. In 2005, 36 lines exhibited AUDPC*c lower than the average of Pc68/ $5 *$ Starter and were considered to be resistant. This ratio adjusted to the model of inheritance governed by the two genes (Table 1). The assessment of the final severity did not allow for adjustment to the models of inheritance, and thus, was not appropriate for this type of analysis. This may be due to the low frequency of the virulent race to Pc68 in the field. In this case, the final severity limits the analysis to one specific moment of the epidemics, which may not consider the severity of the disease that occurred earlier, on lower leaves, that will not be measured later due to the senescence of those leaves. This situation tended to overestimate the number of resistant lines.

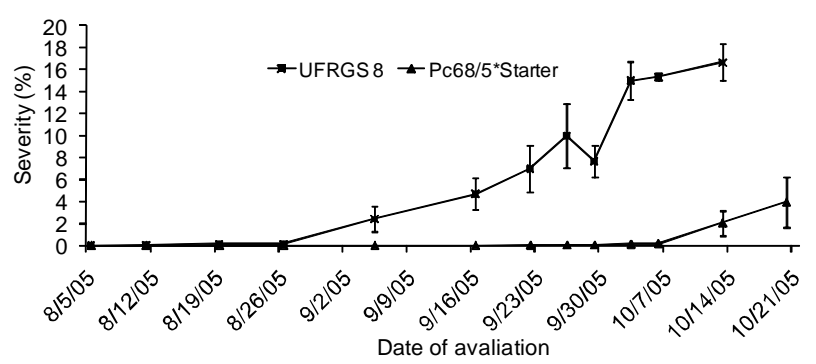

Figure 2 - Progress curve of crown rust on the parent genotypes during 2005 epidemics. Bars represent the standard error of mean.

\section{Discussion}

Resistance to race SQPT of $P$. coronata f.sp. avenae was due to the presence of a single gene, Pc68. Resistance due to another gene is highly unlikely, since the cultivar Starter is susceptible to virtually all races tested in the United States and Pc68/5*Starter was resistant to all races of $P$. coronata. $f$. sp. avenae tested over several years. Furthermore, the parent UFRGS 8 proved to be susceptible to the race SQPT, demonstrating that this cultivar could not have been the donor of this resistance gene. Therefore, the results are in agreement with those obtained by Wong et al. (1983) and Koeyer et al. (2000), indicating that the resistance conferred by the gene Pc68 segregated in the $F_{2}$ generation in the proportions $3: 1$ and $1: 2: 1$, respectively.

Although the results for seedlings have demonstrated that the resistance in the population segregates for the gene Pc68 as a single gene, the data obtained from the field in 2004 indicate that only 32 lines, accounting for $24 \%$ of the total population, were immune to crown rust. The proportion of immune lines clearly indicates that during this year, there were no races in the field that were able to infect the genotypes containing two genes for resistance (AABB). Even without assessing the parent Pc68/5\%Starter in the 2004 field, these data indicate that there were races capable of infecting this genotype, since those lines that had only one gene for resistance, which accounted for $50 \%$ of the total expected population, exhibited some level of infection. These results indicate that the frequency of races capable of infecting genotypes,

Table 1 - Test of goodness of $\chi^{2}$ for segregation models of the resistance in recombinant progenies of oats from the crossing UFRGS 8 with Pc68/5\%Starter.

\begin{tabular}{|c|c|c|c|c|c|c|c|c|c|c|}
\hline \multicolumn{11}{|c|}{ Seedling ${ }^{\mathrm{a}}$} \\
\hline \multirow{3}{*}{\multicolumn{3}{|c|}{ Lines }} & \multicolumn{2}{|c|}{ Number of Lines } & \multicolumn{6}{|c|}{ Theoretical expected proportion (R:S) } \\
\hline & & & \multirow{2}{*}{$\mathrm{R}$} & \multirow{2}{*}{$\mathrm{S}$} & \multicolumn{2}{|c|}{$1: 1$} & & & & \\
\hline & & & & & $\chi^{2 \mathrm{~b}}$ & $\mathrm{P}^{\mathrm{c}}$ & & & & \\
\hline \multicolumn{3}{|c|}{ UFRS 8} & 0 & 60 & & & & & & \\
\hline \multicolumn{3}{|c|}{ Pc68 $/ 5 *$ Starter } & 60 & 0 & & & & & & \\
\hline \multicolumn{3}{|c|}{ Progeny $\mathrm{F}_{5: 6}$} & 62 & 64 & $<0.01$ & 0.93 & & & & \\
\hline \multicolumn{11}{|c|}{ Adult plant } \\
\hline \multirow{2}{*}{ Year $^{\mathrm{d}}$} & \multirow{2}{*}{$\mathrm{N}^{\circ}$ of segregating lines } & \multirow{2}{*}{ Variable $^{\mathrm{e}}$} & \multirow{2}{*}{$\mathrm{R}$} & \multirow{2}{*}{$\mathrm{S}$} & \multicolumn{2}{|c|}{$1: 1$} & \multicolumn{2}{|c|}{$1: 3$} & \multicolumn{2}{|c|}{$3: 1$} \\
\hline & & & & & $\chi^{2 \mathrm{~b}}$ & $\mathrm{Pc}^{\mathrm{c}}$ & $\chi^{2 \mathrm{~b}}$ & $\mathrm{Pc}^{\mathrm{c}}$ & $\chi^{2 \mathrm{~b}}$ & $\mathrm{Pc}^{\mathrm{c}}$ \\
\hline \multirow[t]{2}{*}{2004} & 135 & FS & 53 & 82 & 6.67 & 0.0098 & 12.47 & 0.0004 & 93.89 & $<0.0001$ \\
\hline & 135 & AUDPC ${ }^{*} \mathrm{c}$ & 36 & 99 & 28.48 & $<0.0001$ & $0.12^{*}$ & 0.7280 & 165.62 & $<0.0001$ \\
\hline \multirow[t]{2}{*}{2005} & 134 & FS & 46 & 88 & 13.80 & 0.0002 & 4.81 & 0.0282 & 120.40 & $<0.0001$ \\
\hline & 134 & AUDPC $* \mathrm{c}$ & 36 & 98 & 29.62 & $<0.0001$ & $0.04^{*}$ & 0.8419 & 168.16 & $<0.0001$ \\
\hline
\end{tabular}

a Phenotypes determined by the type of infection present in the lines: Resistant $=\leq$ type of infection (2), Susceptible $=$ type of

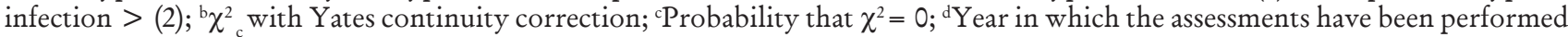
in the field; ${ }^{~}$ Variables used to access the proportion of susceptible and resistant lines. FS $=$ final severity, AUDPC ${ }^{*} \mathrm{c}=$ area under the disease progress curve normalized and corrected; and "Not significant at the $5 \%$ of probability level. $\left(\chi^{2}\right.$ tab (0.05) $\left.=3.841\right)$ 
which contained a single gene for resistance, was low in 2004. The environmental conditions in that year were probably not favorable to a significant increase in the disease resulting from those races. In comparison, a new variant of the pathogen with virulence against Pc68 and the other resistance gene was found in 2005, since none of the lines exhibited immunity in the field. The environmental conditions were more favorable to crown rust in this year, which contributed to genotypes that had only one gene for resistance presenting higher AUDPC*c.

The absence of lines immune to crown rust in 2005 and the presence of lines that were more resistant than the genotype Pc68/5*Starter, suggest the existence of two separate genes for resistance. Thus, the resistant lines must possess genotype $\mathrm{AABB}$ and the susceptible lines any of the following genotypes: $\mathrm{AAbb}, \mathrm{a} a \mathrm{BB}$, or aabb. The genotype Pc68/5*Starter is the source of the Pc68 gene used in this crossing, which confers at least one gene for resistance. However, Pc68/5*Starter is a near isogenic line and might have another resistance gene in addition to Pc68, which would originate from the cultivar Starter. This cultivar demonstrated a degree of resistance upon release in the U.S. (Stuthman et al., 1990), but now it is considered highly susceptible (Díaz-Lago et al., 2002; Leonard, 2002; Leonard, 2003). If the additional gene for resistance was from the genotype Pc68/5*Starter, the resistant recombinant lines would be expected to exhibit levels of FS and AUDPC*c that would be very similar to the resistant parent. Some lines were more resistant than the Pc68/5*Starter, which suggests that a second gene for resistance is present in the cultivar UFRGS 8. In order to clarify this matter further and to validate this model, it would be of value to evaluate this population with a race virulent on $P c 68$ and avirulent on UFGRS 8 , and a race avirulent on both parents. However, there were no such isolates in 2004 and those virulent on Pc68/5*Starter found in the field in 2005 did not develop infection on seedlings when inoculated under controlled conditions, situation that stands until the present date.

On September 22, 2005 (90 DAS), plots sown with the genotype Pc68/5*Starter exhibited traces of crown rust, progressing to levels that ranged from $0.2 \%$ to $10 \%$ in severity with intense development of pustules typical of an infection type (3) at the last evaluation in October 20 (118 DAS), followed by intense development of telia. Despite the wide variation in severity among replicates, the severity of $10 \%$ in one of them, and for the sudden change in the shape of the progress curve towards susceptibility (Figure 2), suggest that this resistance gene was overcome during 2005.

Virulence to plants containing the Pc68 gene found in populations of $P$. coronata f. sp. avenae has been demonstrated experimentally in Brazil (Martinelli, 2000), Canada, USA, (Leonard, 2003), Mexico
(Leonard et al., 2005), Siberia, Uruguay (Leonard and Martinelli, 2005), and Australia (Park, 2000; Oates, 2000). However, the proportions of virulent races for this gene always remained at relatively low levels. Interestingly, the overcoming of this gene in the population has always occurred during a relatively short period of time in different places and environments, as well as under restricted epidemic conditions of the individual populations, such as genetic diversity, complexity, and distinct biological cycles. These results call into question the effectiveness of the use of such resistance genes in breeding programs as well as the strategy of using race specific resistant genes to control this disease.

\section{References}

Ayres, M.; Ayres Jr, M.; Ayres, D.L.; Santos, A.S. 2003. Bioestat 3.0: Statistical Applications in Biological and Medical Science. Sociedade Civil Mamirauá, Belém, PA, Brazil (in Portuguese).

Chong, J.; Leonard, K.J.; Salmeron, J.J. 2000. A North American system of nomenclature for Puccinia coronata f.sp. avenae. Plant Disease 84: 580-585.

Chong, J. 2000. Incidence and virulence of Puccinia coronata in Canada from 1996 to 1998. Canadian Journal of Plant Pathology 22: 99-109.

Díaz-Lago, J.E.; Stuthman, D.D.; Abadie, T.E. 2002. Recurrent selection for partial resistance to crown Rust in oat. Crop Science 42: 1475-1482.

Fry, W.E. 1978. Quantification of general resistance of potato cultivars and fungicide effect for integrated control of potato late blight. Phytopathology 68: 1650-1655.

Koeyer, D.; Orr, W.; Lybaert, A.; Deyl, J.; Chenier, C.; Tinker, N.; Mcelroy, A.; Chong, J.; Molnar, S. 2000. Scar markers linked to the Pc68 resistance allele are an effective tool for selection. p. 137-140. In: Cross, R.J., ed. 2000. Proceedings of the International Oats Conference, 6. New Zealand Institute for Crop \& Food Research, Christchurch, New Zealand.

Leonard, K.J. 2002. Oat line with effective adult plant resistance to crown rust. Plant Disease 86: 593-598.

Leonard, K.J. 2003. Regional frequencies of virulence in oat crown rust in the United States from 1999 through 2000. Plant Disease 87: 1301-1310.

Leonard, K.J.; Huerta-Espino, J.; Salmeron, J.J. 2005. Virulence of oat crown rust in Mexico. Plant Disease 89: 941-948.

Leonard, K.J.; Martinelli, J.A. 2005. Virulence of oat crown rust in Brazil and Uruguay. Plant Disease 89: 802-808.

Martinelli, J.A. 2000. Major diseases on oats in South America. p. 276-282. In: Cross, R.J., ed. 2000. Proceedings of the International Oats Conference, 6. New Zealand Institute for Crop \& Food Research, Christchurch, New Zealand.

Martinelli, J.A.; Federizzi, L.C.; Bennedetti, A.C. 1994. Yield reductions of oat grains due leaf rust severity. Summa Phytopathologica 20: 110-113. (in Portuguese, with abstract in English).

McCallum, B.D.; Fetch, T.; Chong, J. 2007. Cereal rust control in Canada. Australian Journal of Agricultural Research 58: 639647.

Oates, J.D. 2000. Disease on oats! What disease on oats? p. 265275. In: Cross, R.J., ed. Proceedings of the International Oats Conference, 6. New Zealand Institute for Crop \& Food Research, Christchurch, New Zealand.

Park, R.F. 2000. Pathogenic changes in Puccinia coronata (oat crown rust pathogen) with respect to recently deployed crown rust resistance cultivars in Australia. Oat Newsletter 45. Available at: http://wheat.pw.usda.gov/ggpages/oatnewsletter/v45/ [Accessed Jun. 22, 2009] 
Peterson, R.F.; Campbell, A.B.; Hannah, A.E. 1948. A diagrammatic scale for estimating rust intensity on leaves and stems of cereals. Canadian Journal of Research Section 26: 496-500.

Simons, M.D. 1985. Crown rust. p. 131-172. In: Roelfs, A.P.; Bushnell, W.R., eds. The cereal rust. v. II: Diseases, distribution, epidemiology and control. Academic Press, New York, NY, USA.

Sooväli, P.; Koppel, M. 2003. Genetic control of oat rust diseases. Agronomy Research 1: 245-251.

Stuthman, D.D.; Wilcoxson, R.D.; Rines, H.W. 1990. Registration of 'Starter' oat. Crop Science 30: 1365-1366.

Van Kiekerk, B.D.; Pretorius, Z.A.; Boshoff, W.H.P. 2001. Pathogenic viariability of Puccinia coronata f. sp. avenae and $P$. graminis f. sp. avenae on oat in South Africa. Plant Disease 85: 1085-1090.
Wong, L.S.L.; Mckenzie, R.I.H.; Harder, D.E.; Martens, J.W. 1983. The inheritance of resistance to Puccinia coronata and of floret characters in Avena sterilis. Canadian Journal of Genetics and Cytology 25: 391-225.

Zar, J.H. 2009. Biostatistical analysis. 5 ed. Prentice Hall, Upper Saddle River, NJ, USA.

Received July 02, 2009

Accepted March 24, 2010 